\title{
Food resource partitioning in a fish community of the central Amazon floodplain
}

\author{
Bernard de Mérona* and Judy Rankin-de-Mérona**
}

Diets of most of fish species inhabiting a floodplain lake in central Amazonia were studied over a two years and half period. Based on the percentage of relative occurrence of 11 major food categories a classification of species in 11 feeding guilds is proposed. Many species were found to be specialized feeders. Fish, detritus and insects were the most important food resources supporting the fish community in both seasons, but the proportions of fruits, invertebrates and fish were reduced during the low water season. At the community level mean diet overlap between species was low, suggesting efficient resource partitioning within the community. However mean overlap between unspecialized feeders was high. Based on the 23 most abundant species belonging to the different feeding guilds, there was no difference in mean overlap between seasons. Whereas individual species exhibited diet changes between high water and low water seasons, there was no general pattern of seasonal change within feeding guilds.

Os regimes alimentares da maioria das espécies de peixes de um lago de várzea da Amazônia central foram estudados durante dois anos e meio. Baseada nas percentagens de ocorrência relativa de 11 maiores categorias alimentares, uma classificação das espécies em 11 guildas alimentares é proposta. Muitas espécies foram consideradas especializadas em relação aos seus comportamentos alimentares. Peixes, detritos e insetos foram os recursos alimentares mais importantes ao longo do ano, mas as proporções relativas de frutos, invertebrados e peixes foram reduzidas durante a época de águas baixas. A nível de comunidade a sobreposição média entre espécies foi baixa, sugerindo uma partição eficiente dos recursos alimentares. Entretanto, para espécies não especializadas, os valores de sobreposição foram elevados. Baseado em 23 espécies abundantes, pertencentes a diferentes guildas alimentares, não foi observada diferença na sobreposição média entre as estações do ano. Enquanto que certas espécies individuais mostraram mudanças de regime entre épocas de águas altas e baixas, não foi observado nenhuma tendência geral nas modificações sazonais dentro das guildas alimentares.

Key words: varzea lake, fishes, diet, overlap, seasonal variability.

\section{Introduction}

Fish diversity in the Amazon basin is the highest ever observed in freshwaters either at a regional (i.e. the entire Amazon basin) with more than 1300 species (Lowe-McConnell, 1987; Kullander, 1994) or at a local scale (i.e., within selected lakes, wetlands, streams, and rivers within Amazon basin). For example, Junk et al. (1993) captured 132 species in lago Marchantaria, a small floodplain lake in the Solimões near Manaus and Mérona \& Bittencourt (1993) recorded 155 species in the nearby lago do Rei about $100 \mathrm{~km} 2$ large. High local diversity reflects the problem of species coexistence which, following niche theory (Hutchinson, 1957), is based on resource partitioning (Schoener, 1985). Species share three types of resources: food, space and time (Pianka, 1969). However, trophic separation has been pointed out as the most important mechanism of resource partitioning in fish assemblages (Ross, 1986).

There is an abundant literature on the diets of Amazon fishes. Araujo Lima et al. (1995), in a review on trophic aspects of fish communities in Brazil, cite 34 publications dealing directly with diet of Amazonian fish species. However, few of these works consider the entire fish community, which would allow a description of food resource partitioning between species (Marlier, 1968; Knöppel, 1970; Saul, 1975; Ferreira, 1984; Goulding et al., 1988; Mérona et al., 2001; 2003).

The fish community studied here inhabits a floodplain lake in the central Amazon floodplain previously described in Mérona \& Bittencourt (1993). It is characterized by high species richness (155 species) and complex temporal dynamics.

\footnotetext{
*Institut de Recherches pour le Développement (UR131). Antenne IRD, Lab. Ecol. Hydrosystèmes fluviaux, Univ. Cl. Bernard Lyon 1, 43 Bd. du 11 nov. 1918, 69622 Villeurbanne Cedex, France. e-mail: demerona@univ-lyon1.fr

**INPA - Instituto Nacional de Pesquisa da Amazônia. Present address: 8, place Puvis de Chavannes, 69006 - Lyon, France.
} 
We present the results of a study on the feeding habits of the same fish community.

Our study objectives were to i) document the diet and trophic groups of fishes within an Amazon floodplain lake, ii) quantify the seasonal changes in diet and niche breadth of the most abundant species within the floodplain lake, and iii) examine the degree of resource partitioning of food among fishes within the community.

\section{Material and Methods}

The large alluvial island, Ilha do Careiro, is located just southeast of the confluence of the Negro River and the Amazon River (Fig. 1). The island is partly occupied by a permanent floodplain lake, the lago do Rei. This lake is shallow and covers a surface of about $100 \mathrm{~km} 2$ during maximum high water. It has a permanent water connection to the Amazon River by a single outlet channel, the parana do Rei. The water level in the lake follows that of the Amazon River; the mean depth is about $1 \mathrm{~m}$ in the low water season and can reach $10 \mathrm{~m}$ during the high water season. As very flat lands surround the lake, the flood annually inundates large adjacent, mainly forested areas. Most sampling was conducted in the north part: Terra Nova (Fig. 1). In that zone, we sampled all microhabitats available for fish (open waters, border, flooded forest and flooded fields). Additionally we sampled fish from the outlet linking the lake to the Amazon River and in the flooded forest surrounding it.

Fish collections were made by a battery of 13 gillnets ( 50 $\mathrm{m}$ long by 1.5 to $3 \mathrm{~m}$ high) each of different mesh size 15,20 , $25,30,35,40,45,50,55,60,70,80$ and $90 \mathrm{~mm}$ between adjacent knots. We sampled fish every two months from February 1986 to May 1988. Gillnets were set out at about 18:00 hours and checked every six hours until 18:00 hours the next day.

All specimens were identified to species level from Géry (1977), Burgess (1989) and from consultation of specialists (see acknowledgments). Specimens of each species were deposited in the collections of the Instituto Nacional de Pesquisa da Amazônia (INPA, Manaus, Brazil).

The fish were counted and weighed and the capture per unit of effort (the weight of fish captured by $100 \mathrm{~m} 2$ of net during $24 \mathrm{~h}=$ CPUE) was computed for each net and summed for the whole battery. Capture per unit of effort is an index of fish density in the environment. Since large variations in the volume of water in the lake were observed during the hydrological cycle, we corrected the CPUE by an estimation of that volume at the time of sampling. The detailed description of the methodology can be found in Mérona \& Bittencourt (1993). This procedure enabled us to sum up the different samples in order to get an average assemblage for a period.

We examined the stomachs of fish captured from all sampling dates. We only examined the stomachs of adult specimens because juveniles are seldom captured by the sampling methodology adopted. The occurrence of the main food items in the stomachs (i.e. those representing more than about $10 \%$ of the main bulk) was recorded in the field at the time of capture. When identification was impossible in the field, the stomachs were preserved in 10\% formaldehyde and examined in the laboratory under a stereomicroscope. Due to the large number of fish captured (more than 800 specimens per sample on average) every stomach could not be examined and priority was given to omnivorous species whose feeding habits are more difficult to establish. The diets of some abundant fish species have been well established and we only examined 1 to 3 stomachs of these fishes for control. Specifically, fishes with well known diets were curimatids, Curimata cyprinoides, Psectrogaster amazonica, Potamorhina latior, two loricariids, Hypostomus plecostomus and Glyptoperichthys joselimaianus, some famous large predators like Hydrolycus scomberoides and Rhaphiodon gibbus and three planktivores (Hypophtalmus edentatus, $H$. fimbriatus and $H$. marginatus). Data on the diet composition for these species

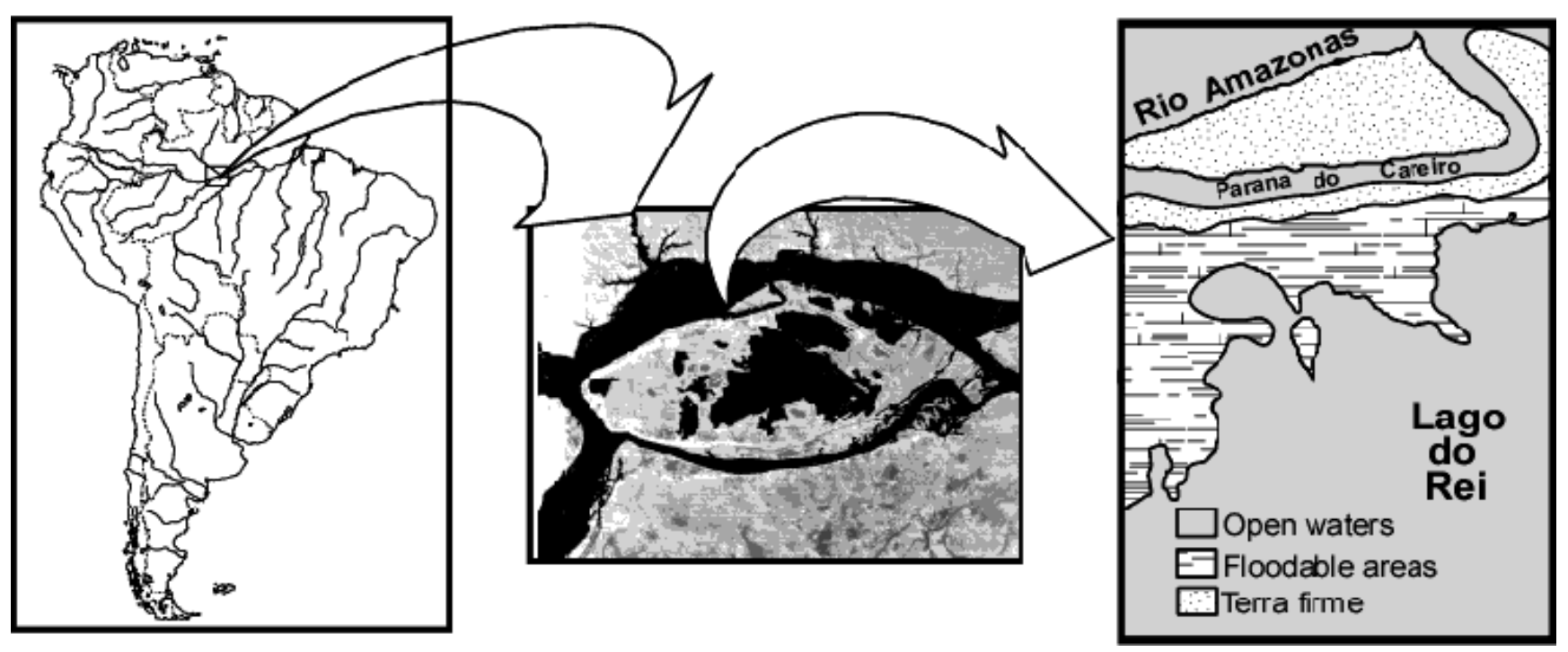

Fig. 1. Localization of the lago do Rei and detail of the study site in the northern part. 
Table 1. Relative abundance (percent) of food items observed in stomachs of 74 species captured in lago do Rei, Brazil, February 1986 to May 1988, and attribution to guilds.

\begin{tabular}{|c|c|c|c|c|c|c|c|c|c|c|c|c|c|}
\hline Species & $\begin{array}{l}\text { 怘 } \\
\text { 总 } \\
\text { 言芯 }\end{array}$ & 施离 & 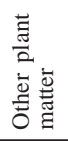 & $\begin{array}{l}\breve{U} \\
\mathscr{E} \\
\Xi\end{array}$ & 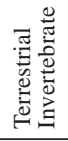 & 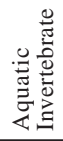 & 直 & 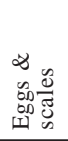 & 语 & 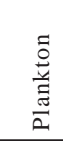 & 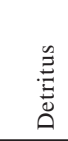 & $\begin{array}{l}\overline{ \pm} \\
\text { D̃ }\end{array}$ & Trophic guild \\
\hline Acaronia nassa & 6 & - & - & 17 & - & - & - & - & 83 & - & - & - & piscivore \\
\hline Acestrorhynchus microlepis & 13 & - & - & - & - & - & - & - & 100 & - & - & - & piscivore \\
\hline Acestrorhynchus falcirostris & 74 & - & - & 1 & - & - & 11 & - & 88 & - & - & - & piscivore \\
\hline Ageneiosus aff. dentatus sp1 & 6 & - & - & - & - & - & 67 & - & 33 & - & - & - & shrimp eater \\
\hline Ageneiosus aff. dentatus sp.2 & 13 & - & - & - & - & - & 100 & - & & - & - & - & shrimp eater \\
\hline Ageneiosus sp.1 & 6 & - & - & 83 & - & - & & - & 17 & - & - & - & insectivore \\
\hline Ageneiosus ucayalensis & 4 & - & - & 25 & - & - & 75 & - & - & - & - & - & shrimp eater \\
\hline Anadoras weddellii & 14 & 19 & 24 & 19 & 14 & 24 & - & - & - & - & - & - & omnivore \\
\hline Anodus elongatus & 3 & - & - & - & - & - & - & - & - & 100 & - & - & planktivore \\
\hline Anodus sp. & 9 & - & - & 22 & - & - & - & - & - & 78 & - & - & planktivore \\
\hline Astronotus ocellatus & 5 & 60 & - & 40 & - & - & - & - & - & - & - & - & omnivore \\
\hline Auchenipterus nuchalis & 46 & - & - & 77 & - & 21 & - & - & 2 & - & - & - & insectivore \\
\hline Brycon carpophagus & 122 & 63 & 6 & 9 & 9 & 1 & 1 & 2 & 7 & 1 & 1 & - & frugivore \\
\hline Brycon melanopterus & 9 & 53 & 7 & 7 & 33 & - & - & - & - & - & - & - & omnivore \\
\hline Calophysus macropterus & 8 & 11 & - & 11 & - & - & - & - & 78 & - & - & - & piscivore \\
\hline Chaetobranchus flavescens & 5 & - & 17 & 17 & - & 67 & - & - & - & - & - & - & aquatic invert \\
\hline Chalceus macrolepidotus & 67 & 49 & - & 30 & 15 & 1 & - & 3 & 2 & - & - & - & omnivore \\
\hline Cichla monoculus & 34 & - & - & - & - & - & 26 & - & 74 & - & - & - & piscivore \\
\hline Cichlassoma amazonarum & 3 & - & - & - & - & - & - & - & - & - & 100 & - & detritivore \\
\hline Colossoma macropoтит & 151 & 59 & 19 & 6 & 4 & 5 & - & 2 & 1 & 5 & - & - & unsp. herbivore \\
\hline Curimata cyprinoides & 3 & - & - & - & - & - & - & - & - & - & 100 & - & detritivore \\
\hline Curimatella meyeri & 10 & - & - & - & - & 9 & - & - & - & - & 91 & - & detritivore \\
\hline Eigenmannina melanopogon & 12 & - & 25 & 8 & - & - & - & - & - & 67 & - & - & planktivore \\
\hline Electrophorus electricus & 5 & - & - & 40 & 20 & - & - & - & 40 & - & - & - & unsp. carnivore \\
\hline Glyptoperichthys joselimaianus & 2 & - & - & - & - & - & - & - & - & - & 100 & - & detritivore \\
\hline Hemiodopsis microlepis & 13 & 7 & 14 & 14 & - & - & - & 50 & - & 7 & 7 & - & omnivore \\
\hline Hemiodus immaculatus & 88 & - & 1 & $9-$ & - & 4 & - & - & 1 & - & 3 & - & insectivore \\
\hline Heros severum & 7 & - & 31 & 15 & - & 8 & - & 15 & - & - & 31 & - & omnivore \\
\hline Hoplerythrinus unitaeniatus & 89 & 55 & - & 9 & 7 & - & - & 6 & 24 & - & - & - & omnivore \\
\hline Hoplias malabaricus & 49 & - & 2 & - & - & - & 4 & 2 & 92 & - & - & - & piscivore \\
\hline Hoplosternum littorale & 7 & - & 10 & 10 & 10 & 60 & - & 10 & - & - & - & - & aquatic invert \\
\hline Hydrolycus scomberoides & 3 & - & - & - & - & - & - & - & 100 & - & - & - & piscivore \\
\hline Hypophthalmus edentatus & 3 & 25 & - & - & - & - & - & - & - & 75 & - & - & planktivore \\
\hline Hypophthalmus fimbriatus & 3 & - & - & - & - & - & - & - & - & 100 & - & - & planktivore \\
\hline Hурорhthalmus cf. marginatus & 2 & - & 33 & - & - & - & - & - & - & 67 & - & - & planktivore \\
\hline Hypostomus plecostomus & 3 & - & - & - & - & - & - & - & - & - & 100 & - & detritivore \\
\hline Leporinus friderici & 42 & 50 & 24 & 5 & 6 & 8 & 2 & 2 & 3 & - & - & - & omnivore \\
\hline Leporinus trifasciatus & 9 & 89 & 11 & - & - & 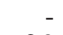 & - & - & - & - & - & - & frugivore \\
\hline Loricariichthys acutus & 4 & 14 & - & 43 & - & 29 & - & - & - & - & 14 & - & omnivore \\
\hline Lycengraulis grossidens & 35 & - & - & - & - & - & 3 & - & 97 & - & - & - & piscivore \\
\hline Mylossoma aureum & 13 & 81 & 13 & - & - & 6 & - & - & - & - & - & - & frugivore \\
\hline Mylossoma duriventre & 60 & 70 & 4 & 4 & 6 & 15 & - & - & - & - & - & - & frugivore \\
\hline Osteoglossum biccirhosum & 132 & 3 & 18 & 54 & 4 & 4 & 4 & 1 & 10 & - & - & 1 & unsp. carnivore \\
\hline Parauchenipterus galeatus & 37 & 25 & 10 & 46 & 8 & 4 & - & 2 & 2 & - & 2 & - & omnivore \\
\hline Parauchenipterus sp.2 & 168 & 14 & 10 & 41 & 7 & 6 & 1 & 2 & 19 & - & - & - & unsp. carnivore \\
\hline Pellona castelneana & 45 & - & - & 2 & - & 4 & 19 & - & 74 & - & - & - & piscivore \\
\hline Pellona flavipinnis & 119 & - & 1 & 31 & - & 8 & 36 & - & 24 & - & - & - & unsp. carnivore \\
\hline Piaractus brachypoтиs & 14 & 52 & 22 & - & 13 & 9 & - & - & - & - & 4 & - & unsp. herbivore \\
\hline Pimelodus blochii & 32 & 17 & 7 & 39 & 4 & 22 & 4 & 2 & 4 & - & - & - & unsp. carnivore \\
\hline Plagioscion montei & 88 & - & - & 14 & 5 & 3 & 43 & - & 35 & - & - & - & unsp. carnivore \\
\hline Plagioscion squamosissimus & 90 & - & - & 6 & - & 2 & 58 & - & 33 & - & - & - & unsp. carnivore \\
\hline Potamorhina altamazonica & 18 & - & 5 & - & - & - & - & - & - & - & 95 & - & detritivore \\
\hline Potamorhina latior & 1 & - & - & - & - & - & - & - & - & - & 100 & - & detritivore \\
\hline Prochilodus nigricans & 14 & 13 & 33 & - & - & 7 & - & - & - & - & 47 & - & unsp. herbivore \\
\hline Psectrogaster amazonica & 3 & - & - & - & - & - & - & - & - & - & 100 & - & detritivore \\
\hline Psectrogaster sp.1 & 6 & - & - & - & 14 & - & - & - & - & - & 86 & - & detritivore \\
\hline Pseudodoras niger & 7 & 30 & 10 & - & - & 60 & - & - & - & - & - & - & aquatic invert \\
\hline Pseudostylosurus sp. & 7 & - & - & - & - & - & - & - & 100 & - & - & - & piscivore \\
\hline Pterodoras granulosus & 35 & 40 & 58 & - & - & 2 & - & - & - & - & - & - & unsp. herbivore \\
\hline Pygocentrus nattereri & 190 & 2 & 17 & 7 & - & 1 & 1 & 3 & 67 & - & - & 1 & piscivore \\
\hline Rhaphiodon gibbus & 2 & - & - & - & - & - & - & - & 100 & - & - & - & piscivore \\
\hline Rhaphiodon vulpinus & 17 & - & - & - & - & - & 18 & - & 82 & - & - & - & piscivore \\
\hline Rhytiodus argenteofuscus & 5 & 40 & 20 & 40 & - & - & - & - & - & - & - & - & omnivore \\
\hline Rhytiodus microlepis & 99 & 2 & 96 & - & - & 1 & - & 1 & - & - & - & - & leaf eater \\
\hline Schizodon fasciatum & 100 & 13 & 80 & 1 & 3 & 2 & - & 2 & - & - & - & - & leaf eater \\
\hline Semaprochilodus theraponura & 4 & - & 20 & - & - & - & - & - & - & - & 80 & - & detritivore \\
\hline Serrasalmus elongatus & 47 & - & 4 & 4 & - & - & - & 4 & 85 & - & - & 2 & piscivore \\
\hline Serrasalmus rhombeus & 5 & - & 17 & 17 & - & - & 17 & - & 50 & - & - & - & unsp. carnivore \\
\hline Serrasalmus sp. 3 & 61 & 13 & 9 & 29 & - & 4 & 3 & 3 & 38 & - & - & - & unsp. carnivore \\
\hline Serrasalmus spilopleura & 94 & 20 & 8 & 16 & - & 2 & 2 & 9 & 42 & - & - & - & omnivore \\
\hline Sorubim lima & 31 & - & - & 94 & - & - & - & - & 6 & - & - & - & insectivore \\
\hline Sternopygus macrurus & 31 & - & 11 & 66 & - & 9 & 11 & 3 & - & - & - & - & insectivore \\
\hline Triportheus albus & 23 & - & - & 78 & - & 22 & - & - & - & - & - & - & insectivore \\
\hline Triportheus angulatus & 434 & 37 & 6 & 34 & 13 & 5 & - & 4 & 1 & - & - & 1 & omnivore \\
\hline Triportheus elongatus & 211 & 37 & 3 & 33 & 20 & 4 & - & 2 & - & - & - & 1 & omnivore \\
\hline
\end{tabular}


Table 2. Relative abundance (percent) of food items observed in stomachs of selected species and niche breath during low (LW) and high water (HW) seasons in lago do Rei, Brazil.

\begin{tabular}{|c|c|c|c|c|c|c|c|c|c|c|c|c|c|c|}
\hline Species & & 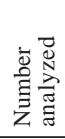 & 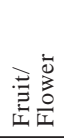 & 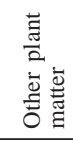 & 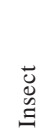 & 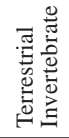 & 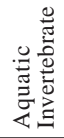 & 章 & 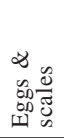 & $\frac{\pi}{\sqrt[n]{2}}$ & 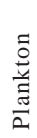 & 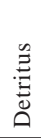 & $\stackrel{\bar{D}}{\tilde{0}}$ & 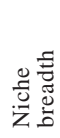 \\
\hline \multicolumn{15}{|l|}{ Piscivore } \\
\hline \multirow{2}{*}{ Acestrorhynchus falcirostris } & HW & 26 & - & - & - & - & - & - & - & 100 & - & - & - & 1.00 \\
\hline & LW & 35 & - & - & - & - & - & 23 & - & 77 & - & - & - & 1.54 \\
\hline \multirow[t]{2}{*}{ Cichla monoculus } & HW & 10 & - & - & - & - & - & - & - & 100 & - & - & - & 1.00 \\
\hline & LW & 21 & - & - & - & - & - & 43 & - & 57 & - & - & - & 1.96 \\
\hline \multirow[t]{2}{*}{ Hoplias malabaricus } & HW & 14 & - & - & - & - & - & 7 & 7 & 86 & - & - & - & 1.34 \\
\hline & LW & 30 & - & 3 & - & - & - & 3 & - & 93 & - & - & - & 1.15 \\
\hline \multirow[t]{2}{*}{ Pellona castelneana } & HW & 26 & - & - & 4 & - & 7 & 18 & - & 71 & - & - & - & 1.82 \\
\hline & LW & 14 & - & - & - & - & - & 21 & - & 79 & - & - & - & 1.51 \\
\hline \multirow[t]{2}{*}{ Serrasalmus elongatus } & HW & 26 & - & 4 & 4 & - & - & - & 4 & 89 & - & - & - & 1.26 \\
\hline & LW & 18 & - & 6 & 6 & - & - & - & 6 & 78 & - & - & 6 & 1.62 \\
\hline \multirow[t]{2}{*}{ Pygocentrus nattereri } & HW & 139 & 1 & 15 & 7 & - & 1 & 1 & 3 & 69 & - & - & 1 & 1.97 \\
\hline & LW & 26 & - & 28 & 14 & - & 3 & 3 & 3 & 48 & - & - & - & 3.01 \\
\hline \multicolumn{15}{|l|}{ Frugivore } \\
\hline \multirow[t]{2}{*}{ Mylossoma duriventris } & HW & 27 & 79 & - & 11 & - & 11 & - & - & - & - & - & - & 1.56 \\
\hline & LW & 9 & 56 & 33 & - & - & 11 & - & - & - & - & - & - & 2.31 \\
\hline \multicolumn{15}{|l|}{ Leaf eater } \\
\hline \multirow{2}{*}{ Rhytiodus microlepis } & HW & 58 & 2 & 98 & - & - & - & - & - & - & - & - & - & 1.03 \\
\hline & LW & 22 & - & 100 & - & - & - & - & - & - & - & - & - & 1.00 \\
\hline \multirow[t]{2}{*}{ Schizodon fasciatum } & HW & 42 & 16 & 80 & 2 & - & 2 & - & - & - & - & - & - & 1.50 \\
\hline & LW & 17 & - & 100 & - & - & - & - & - & - & - & - & - & 1.00 \\
\hline \multicolumn{15}{|l|}{ Insectivore } \\
\hline \multirow[t]{2}{*}{ Hemiodus immaculatus } & HW & 83 & - & 1 & 96 & - & - & - & - & 1 & - & 1 & - & 1.08 \\
\hline & LW & 5 & - & - & 40 & - & 40 & - & - & - & - & 20 & - & 2.78 \\
\hline \multirow{2}{*}{ Sternopygus macrurus } & HW & 13 & - & 7 & 64 & - & 21 & 7 & - & - & - & - & - & 2.13 \\
\hline & LW & 17 & - & 11 & 74 & - & - & 16 & - & - & - & - & - & 1.73 \\
\hline \multicolumn{15}{|l|}{ Unsp. herbivore } \\
\hline Colossoma macropoтит & HW & 42 & 88 & 7 & - & 2 & - & - & 2 & - & - & - & - & 1.28 \\
\hline & LW & 28 & 15 & 41 & 29 & - & 12 & - & - & 3 & - & - & - & 3.42 \\
\hline Unsp. carnivore & & & & & & & & & & & & & & \\
\hline Osteoglossum biccirhosum & HW & 50 & 7 & 18 & 49 & 1 & 6 & 1 & 1 & 15 & - & - & - & 3.26 \\
\hline & LW & 66 & 1 & 20 & 57 & 3 & 1 & 8 & - & 8 & - & - & 2 & 2.67 \\
\hline Parauchenipterus sp.2 & HW & 98 & 23 & 13 & 46 & 6 & 5 & 1 & 1 & 4 & - & - & - & 3.50 \\
\hline & LW & 28 & - & 6 & 56 & 3 & 13 & - & 3 & 19 & - & - & - & 2.68 \\
\hline Serrasalmus sp. 3 & HW & 43 & 15 & 6 & 35 & - & 2 & 4 & - & 38 & - & - & - & 3.41 \\
\hline & LW & 13 & - & 21 & 21 & - & 14 & - & - & 43 & - & - & - & 3.38 \\
\hline Pellona flavipinnis & HW & 39 & - & - & 60 & - & 16 & 9 & - & 16 & - & - & - & 2.40 \\
\hline & LW & 80 & - & 1 & 17 & - & 4 & 49 & - & 29 & - & - & - & 2.83 \\
\hline Plagioscion montei & HW & 53 & - & - & 11 & 4 & 2 & 43 & - & 41 & - & - & - & 2.77 \\
\hline & LW & 31 & - & - & 22 & - & 5 & 41 & - & 32 & - & - & - & 3.13 \\
\hline Plagioscion squamosissimus & HW & 49 & - & - & 11 & - & 2 & 53 & - & 34 & - & - & - & 2.45 \\
\hline & LW & 36 & - & - & - & - & 3 & 68 & - & 30 & - & - & - & 1.83 \\
\hline Omnivore & & & & & & & & & & & & & & \\
\hline Leporinus friderici & HW & 11 & 46 & 23 & 15 & - & - & - & - & 15 & - & - & - & 3.19 \\
\hline & LW & 16 & 71 & 18 & - & - & - & 6 & 6 & - & - & - & - & 1.86 \\
\hline Serrasalmus spilopleura & HW & 28 & - & 10 & 23 & - & 3 & - & 13 & 52 & - & - & - & 2.90 \\
\hline & LW & 57 & 30 & 8 & 16 & - & 2 & 3 & 5 & 36 & - & - & - & 3.93 \\
\hline Triportheus angulatus & HW & 278 & 42 & 7 & 46 & 2 & 2 & - & - & 1 & - & - & - & 2.57 \\
\hline & LW & 38 & 2 & 10 & 76 & - & 10 & - & 2 & - & - & - & - & 1.69 \\
\hline Triportheus elongatus & HW & 129 & 42 & 2 & 49 & 2 & 4 & - & 1 & - & - & - & - & 2.38 \\
\hline & LW & 18 & - & 14 & 76 & - & 10 & - & - & - & - & - & - & 1.64 \\
\hline
\end{tabular}

can be found in Marlier (1968), Saul (1975), Santos et al. (1984), Soares et al. (1986), Goulding et al. (1988), Planquette et al. (1996), LeBail et al. (2000), Mérona et al. (2001), and Mérona et al. (2003). Many rare species yielded no information either because the few collected stomachs were empty or because they were kept in the systematic collections of INPA and therefore were excluded from the analyses.

The 11 food items considered were Fruit/Flower - fruits, seeds and flowers, Vege - vegetative parts of higher plants, predominantly leaves, Inse - unidentifiable insect fragments (In many stomachs the macroscopic examination was unable to identify the terrestrial or aquatic origin of the insect remains), Invt - terrestrial invertebrates, including winged insects, ants, termites, snails and centipedes, Inva - aquatic invertebrates, including insect larvae and pupae, worms and aquatic snails, Shrimp - shrimps (Shrimps were considered separately from other aquatic invertebrates because of their great abundance in the lake and the presence of fish species selecting this type of prey (Goulding \& Ferreira, 1984)), Plank- ton - zooplankton or phytoplankton, Egg/Scale - fish scales or undetermined eggs (separated from the resource fish because consuming this type of food is associated to a different feeding behavior), Fish - fish flesh, fins or bones, Detritus - detritus, organic layer, periphytic algae and mud, Other pieces of terrestrial vertebrates, feathers, wood fragments.

We computed the percentage of relative occurrence for each item, i.e. for each species, the number of occurrences of each food item divided by the total number of occurrences of all the items. Given that the method adopted focused on the main food items in the stomach, that is those that occupy a significant volume in the stomach, no more precise estimation of volume was made.

The placement of species in feeding guilds was determined by successively separating groups of species with stomach contents composed of more than $60 \%$ of a single food item, and leaving at the end those omnivorous species with no marked dominance of a given food category (see Table 1). 
A broad estimation of the relative importance of the resources supporting the fish community was obtained by distributing the captured biomass of each species over the different food categories based on their relative contribution in the stomachs (Mérona et al., 2001; 2003). According to Winemiller (1989) this procedure permits to take into account only the food resources that the fish can effectively access. Seasonal change in the pattern of relative contributions of resources was tested by a chi-square test. To perform the test, items with low contribution values were grouped together: insects, terrestrial invertebrates, aquatic invertebrates and plankton in invertebrates; other and unknown in unknown.

For some species we compared the efficiency of resource partitioning in the low water season when only open water is available to fish (October and December 1986, September, October and December 1987) and high water season when forest and marginal fields are inundated (June and August 1986, April and June 1987). Data from intermediate hydrological stages (February 1986, 1987 and 1988) were excluded from this comparison. The mean percentage of relative occurrence of each food category was computed separately for the two seasons and symmetric overlaps between species diet were calculated using the formula of Morisita (1959). Morosita's index and its relatives (Horn, 1966; Pianka, 1973) generate overlap values ranging form zero to one, and are the most frequently used overlap indices (Linton et al., 1981). Generally values equal or greater than 0.60 are assumed to represent high dietary overlap (Zaret \& Rand, 1971). Differences in mean overlap between seasons were tested by a t-test. Diet composition was compared between the two seasons. Niche breadth was calculated as the inverse sum of the squared proportions of the relative occurrences of the food items in the stomachs (Levins, 1968).

\section{Results}

We were able to examine the stomach contents and determine the diets of 74 of 140 fish species captured in the lago do Rei (Table 1). These species represented $94 \%$ of the total fish biomass captured during the period February 1986 to May 1988.

Examination of fish diets (Table 1) suggested the presence of 11 trophic groups within the fish community. Only 27 of the 74 species had a diversified diet and were classified either in the omnivore feeding guild, when animal and vegetal food are consumed in approximately equal parts, or in the unspecialized herbivore or carnivore guilds when only food of vegetal or animal origin was found in the stomachs. The 47 other species had a diet dominated by a single food item. Planktivores had more than $65 \%$ relative occurrence of plankton in their stomachs. Detritivores' stomachs were full of a mushy substance with few recognizable items at a macroscopic level. This was apparently either mud of a brown color, or a green paste made of periphyton. Piscivores consumed fish for more than $65 \%$ relative occurrence of their diet. Shrimp eaters were also predatory fishes but with a marked preference for shrimps which composed 65 to $100 \%$ relative occurrence in their diet depending on the species. Frugivores were specialized in consuming fruits or seeds, items that represented more than $60 \%$ of the mean relative occurrence in their stomachs. Leaf eaters ate predominantly vegetative parts of vascular plants. Stomachs of insectivores contained undetermined insect remains. Species grouped in this guild are very heterogeneous in their morphology and their preys are probably of diverse origin, either aquatic or terrestrial. In some cases nevertheless aquatic insect larvae were easily recognizable and, together with other benthic animals, allowed the definition of a guild of aquatic invertebrate predators.

There was a significant difference in the relative contribution of the food categories supporting the fish community between seasons (chi-square $=86.99 ; \mathrm{df}=6 ; \mathrm{p}<0.001$ ). In both seasons, fish, detritus and insects were the most abundant food resources exploited by the Terra Nova fish community (Fig. 2). Higher plant vegetative parts appeared to be a constant resource whereas the relative proportion of fruits or seeds and, to a lesser extent, invertebrates and fish, were reduced from the high water to the low water season. In the low water season, detritus composed a greater proportion of the resources when other resources were apparently in short supply.

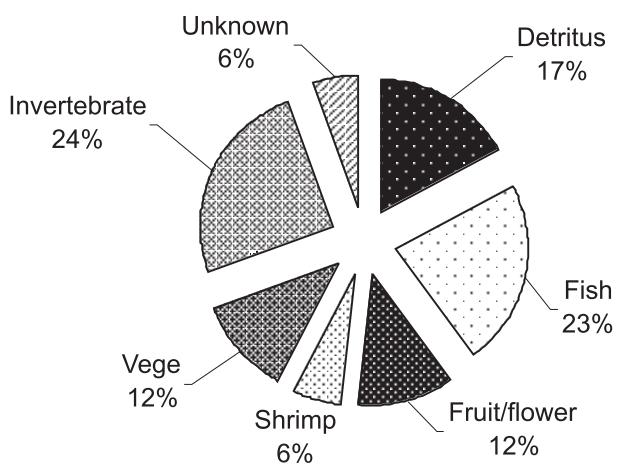

HIGH WATER SEASON

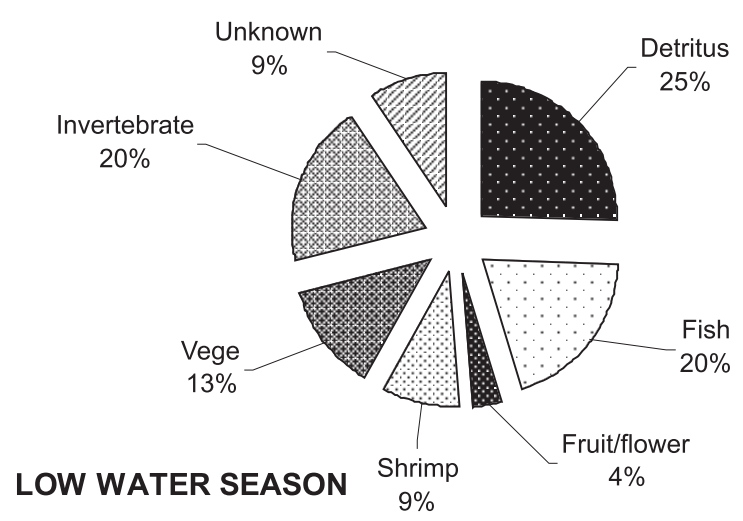

Fig. 2. Relative importance of food categories in supporting the community's biomass of fish species inhabiting a floodplain lake (lago do Rei) in Central Amazonia in the two seasons. 
When considering the whole community in Terra Nova, the mean overlap between diets was very low $(0.238)$ showing a high degree of food partitioning between species (Fig. $3 \mathrm{~A})$. However, among the generalist species, the mean overlap was much greater (Fig. 3 B). On the 23 species where stomach content data were sufficient we observed no difference between mean overlaps in the two contrasted seasons $(n=253 ; t=-0.109 ; p=0.913)$ (Fig. 3 C). However, some individual species showed modifications in their feeding habits (Table 2). Four out of six piscivores enlarge their niche breath in the low water season, part of their fish food being substituted by shrimps or even plant matter. Consumption of fruits in Mylossoma duriventris and Colossoma macropomum was much reduced in the low waters and substituted by plant vegetative parts plus invertebrates. Conversely Leporinus friderici ate a greater proportion of seeds during the low water season. Omnivore species generally narrowed their dietary niche breadth in the low water season with the exception of a piranha species, Serrasalmus spilopleura, which increased its consumption of fruits and seeds.

\section{Discussion}

\section{Specialists versus generalists}

It is an accepted generalization that riverine fish species are mostly opportunistic in their feeding habits because of the ephemeral character of habitats and resources (LoweMcConnell, 1987; Araujo Lima et al., 1995). Nevertheless, many Amazonian fish species exhibit marked morphological adaptations to a particular type of food (Pouilly et al., 2003). In this study we were able to differentiate eight types of specialized feeding behaviors, based on plankton, detritus, leaves, insects, aquatic invertebrates, fruits, fish and shrimp. This could be the expression either of opportunistic species occasionally sharing the great diversity of food resources of the floodplain, or of adaptive selection of specialist species able to feed only upon one particular type of prey because of morphological, anatomical or physiological attributes. If truly specialized, then these species might be expected to have the same diet in different environments (i.e. show a low flexibility in their diet).

Carvalho \& Goulding (1985) observed a high consistency in the planktivorous diet of Hypophthalmus fimbriatus, and their result suggested that a decrease in plankton abundance resulted in a decrease in food intake rather than an increase in niche breath. In a different environment, Carvalho (1978) and Carvalho et al. (1978) described a phytoplanktophagous diet for Hypophthalmus perporosus (probably a synonym of Hypophthalmus marginatus, see Santos et al., 1984) in the lower Tocantins River. The species lives in the pelagic compartment of a large clear-water river where phytoplankton production is high (Schmidt, 1982). Planktophagous diets were also reported in other floodplain lakes of central Amazonia for Anodus laticeps (probably a synonym of one of the Anodus species captured in the present study) (Marlier, 1968) and for Hypophthalmus edentatus (Carvalho, 1980). In reservoirs
Hypophthalmus marginatus, H. edentatus and Anodus elongatus are also planktivores (Hahn et al., 1998; Mérona et al., 2001). These data show that plankton represents the obligatory food resource for these species. This specialization explains why the distributions of these species are limited to environments including a large pelagic compartment allowing the development of plankton.

Many fish species classified as detritivores exhibit the same kind of diet in other habitats. Detritus constitutes the main food source for Potamorhina latior along the beaches and into the inundated forest of the Negro River (Goulding $e t$ al., 1988) Semaprochilodus theraponura feeds on detritus
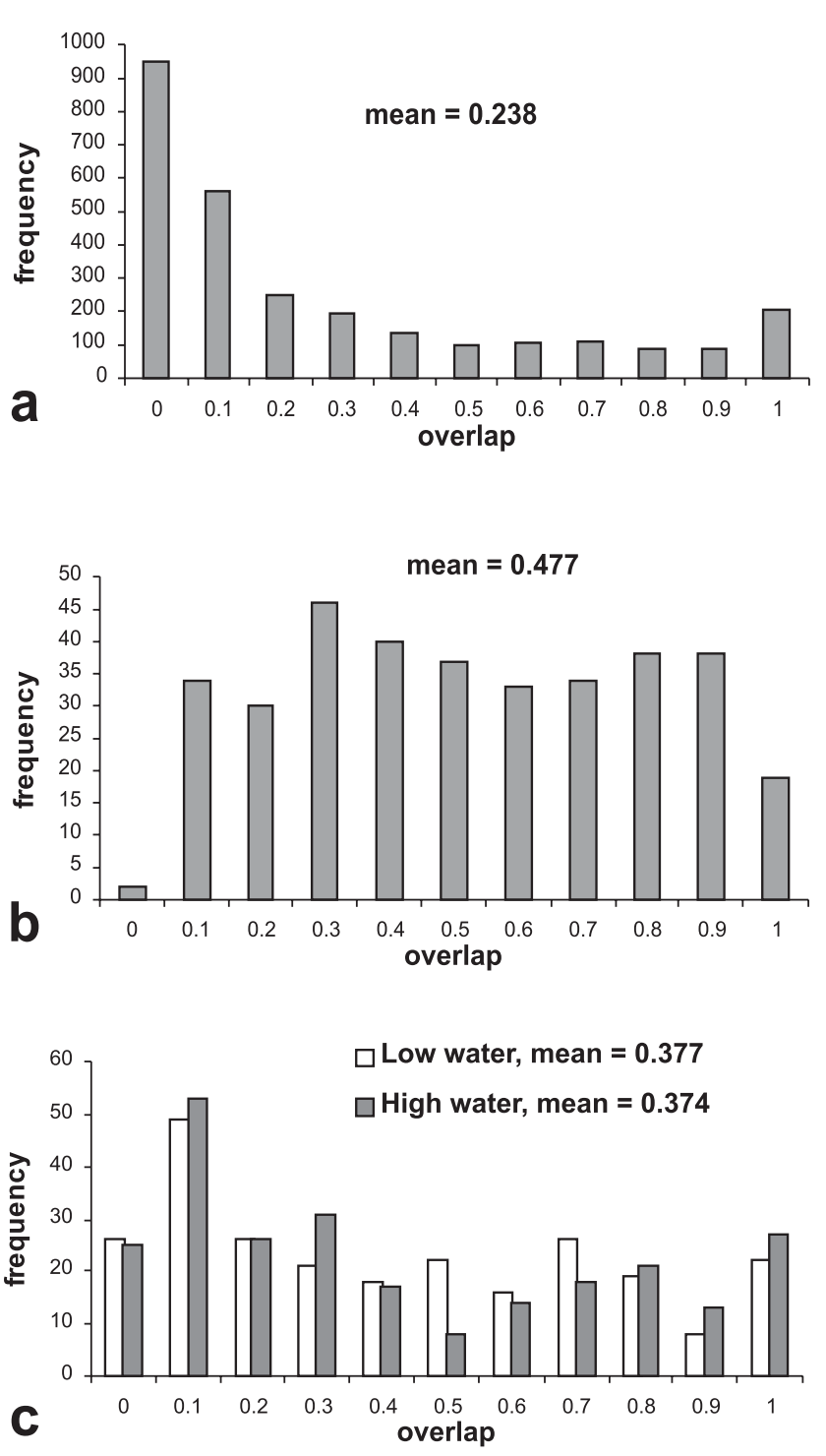

Fig. 3. Distribution of overlaps values between diets of fish species inhabiting a floodplain lake (lago do Rei) in Central Amazonia. a: whole community all seasons (74 species); b: generalist species all seasons (27 species); and c: seasonal differences ( 23 species). 
mixed with sand in the different habitat types of Curuá-Una reservoir (Ferreira, 1984) and a small forested creek in Central Amazon (Knöppel, 1970). The diet of Glyptoperichthys joselimaianus (=Pterygoplichthys multiradiatus) consists of mud or fine sediment in Central Amazonia (Marlier, 1968). Regardless the food type ingested, the feeding behavior of these detritivore species, scraping of the benthic layer, appears to be a fixed character that goes with morphological adaptations.

Two species are considered here as exclusive leaf eaters. Schizodon fasciatum and Rhytiodus microlepis were studied in the Madeira River (Goulding, 1980), other rivers in the state of Rondônia (Santos, 1991) and another floodplain lakes (Santos, 1981) and were always reported to consume vegetative parts of higher plants sometimes supplemented by algae.

Frugivory in Amazonian fishes is a well-recognized phenomenon since the works of Gottsberger (1978) and Goulding (1980). Species of the sub-family Serrasalminae (genus Piaractus, Colossoma, Mylossoma, and Myleus) and of the genus Brycon have already been described as fruit and seed eaters (Honda, 1974; Goulding, 1980; Goulding et al., 1988). Fruit eating is evidently much reduced during the low water period when the fruit sources in the forests are not accessible to fish. In these periods the frugivores ingest more seeds than fruits supplementing their diet with other kind of food such as plankton, detritus or leaves. This change in feeding behavior associated with reduced availability of fruits during periods of low water explains why we did not classify Colossoma macropomum as frugivore. Furthermore, Goulding (1980) found that overall food intake is much lower during this period than in the high water period.

Piscivores formed the largest guild in the lago do Rei with 14 species thus classified in our analysis. The diets of most piscivores from our study area have been examined in other geographic locations and typically exhibited a piscivorous diet in those locations. In the upper Madeira River, Pellona castelneana and Cichla ocellaris (=C. monoculus?) consume only fish (Goulding 1980). The same feeding regime is described in different Rio Negro habitats for Acestrorhynchus falcirostris and A. microlepis (Goulding et al., 1988). Hoplias malabaricus is also an exclusive piscivore in the Tocantins River and in the Sinnamary River in French Guiana (Mérona et al., 2001; 2003) although its diet is more diverse in the Venezuela Llanos but always dominated by fish (Winemiller, 1989). Conversely, Pygocentrus nattereri seems to be able to feed on alternative food sources. In the Pantanal of Mato Grosso in Brazil, this species consumes plant matter, crabs and insects as frequently as fish (Sazima \& Machado, 1990).

In contrast to the guilds mentioned above whose species are in the majority true specialists, three guilds encountered in lago do Rei contain species with apparently more flexible diets.

Species classified here as insectivores are of two types. Auchenipterus nuchalis and Triportheus albus are surface feeders that have already been reported to feed preferentially upon terrestrial insects associated with allochthonous plant material (Horeau et al., 1996; Mérona et al., 2001). The other species form a heterogeneous group. Sternopygus macrurus and Hemiodus immaculatus are predators of aquatic invertebrates and/or aquatic plants (Knöppel, 1970; 1972; Goulding et al., 1988). Sorubim lima was considered as a shrimp-eating specialist in the Rio Madeira floodplain by Goulding \& Ferreira (1984).

The two Plagioscion species were intensively studied in Amazonian floodplain lakes (Annibal, 1982; Wortmann, 1982) and some data also exist on their food habits in other habitats (Goulding \& Ferreira, 1984; Mérona et al., 2001). Despite a marked preference for shrimp, it appears that these species, as is also true for Ageneiosus species, are better described as unspecialized carnivores rather than shrimp eating specialists. Depending on the availability of shrimp in the environment these species are also able to prey on fish or insects (Hahn et al., 1997).

Only three species have a diet largely restricted to aquatic invertebrates in the Lago do Rei. One, Chaetobranchus flavescens is a cichlid, a family whose members generally have a very diverse diet (Ferreira, 1981). Two other species are bottomdwelling siluriforms and their food is poorly known. In the flooded forest of the Madeira basin the diet of Pseudodoras niger (synonym of Oxydoras niger) is composed of aquatic insect larvae mixed with detritus (Goulding, 1980). The same feeding regime is observed in the Tocantins River (Mérona et al., 2001). Therefore, consuming aquatic invertebrates does not seem to be, for these species, a feeding specialization. They are rather benthic feeders, which select their food from what is available on the bottom.

\section{The food resource}

Fish and the organic layer together represent the majority of the resources used by the adult fish community in the Lago do Rei. A number of data suggest that many migratory species in the Amazon River basin reproduce in the main stream of the white water rivers and that their larvae and juveniles are passively transported to the floodplain at the time of the rising of the waters (Schwassmann, 1978; CoxFernandes \& Mérona, 1988; Petry, 1989; Araujo Lima, 1994; Cox-Fernandes, 1997). Therefore fish constitutes a large and probably non-limiting resource in the floodplain, even more available in the high water season, which corresponds to the growing season for most of the species. The organic layer that in our definition includes detritus, mud and epiphytic algae, is also an extremely abundant resource. Detritus and mud originate from the deposition of material brought by the river and from the total or partial decomposition of the forest litter incorporated in the aquatic environment during flooding. Epiphytic production is boosted by the great quantity of nutrients (Kern \& Darwich, 1997; Weber, 1997). In the low water period, the organic layer compensates for the shortage in other resources. Insects, either terrestrial or aquatic, support a large biomass of the fish community. During the high water, when the forest is inundated, a number of terrestrial insects fall in the water and are preyed upon by fish. The relative importance of insects and fruits, two resources that 
are for a large part derived from the flooded forest, is reduced in the dry season when the only habitat available for fish is the open water. The contribution of shrimp is higher in the low water season. Macrobrachium amazonicum was the most abundant species of shrimp in lago do Rei during our study. M. amazonicum reproduces all year, but its maximum reproductive output occurs during the low water season (OdinetzCollart, 1991). Plankton provides only a small part of the available resource. Its development in the floodplain is limited by the low transparency (Schmidt, 1973; Brandorff, 1977).

\section{Resource partitioning}

The analysis of dietary overlaps shows that resource partitioning is well defined with low overlap overall at the community level in both seasons. Not surprising, overlaps are much higher for the unspecialized feeding guilds. In a study on a tropical stream fish community in Panama, Zaret \& Rand (1971) observed reduced diet overlaps between species during the dry season, which they attributed to a shortage in food resources. They stated that this observation supported the competitive exclusion principle arguing that a reduction in niche dimensions lowers the level of competition between species. These findings are in contradiction with Lowe McConnell's (1964) observations on fish communities in the Rupununi River. Her conclusion was that diets are more specialized during the high water season when foods are varied and plentiful than in the dry season where fish share the little food available. Goulding (1980) and Goulding et al. (1988) based on observations on fish communities from Rio Machado and Rio Negro agreed with Lowe McConnell's hypothesis, although they showed that many species share the same items during the flood. Nevertheless our findings, based on 23 species belonging to various different feeding guilds, do not show any general tendency in the seasonal pattern of overlaps between species. It appears that the response to a shortage in food supply can be different depending on the species and not on the guild. On the four omnivores studied, three narrowed their diet in the low water season either in preying more on insect (Triportheus spp.) or in concentrating on seeds (Leporinus friderici) and just one enlarged it. This suggests that other mechanisms must exist which allow the co-existence of species in very complex fish communities. LoweMcConnell (1964) and Goulding (1980) suggested that the fact that many species reduce their food intake during the dry season, consuming the fat accumulated during the wet season, play a role in lowering the level of competition. Partitioning of space at different times could be another way to enhance co-existence (Pianka, 1969; Ross, 1986).

\section{Conclusions}

The Amazon floodplain with its diverse fish fauna represents a unique opportunity to understand how species coexist. According to classical niche theory (Hutchinson, 1957) one way to achieve co-existence is to use separate resources of the environment. Food, space and time are resources likely to be partitioned by fish. The data presented here lead to three main conclusions:

- many fish species (41 out of 74 studied here) exhibit a specialized diet in the diverse fish community of central Amazonia which leads to an overall efficient food partitioning in this community,

- there is a large seasonal variation in the food resource supporting the fish community related to the accessibility of flooded terrestrial areas,

- individual species generally change their feeding habits in the low water season when some food resources are scarce but there is no general tendency observed at the community or at the feeding guild levels.

\section{Acknowledgements}

This work was part of an interdisciplinary project partly funded by European Community and with the support of INPA (Instituto Nacional de Pesquisa da Amazônia, and ORSTOM (Institut français de Recherche Scientifique pour le Développement en Coopération). The field work could not be done without the efficient collaboration of the technical staff of Peixe e Pesca department of INPA. We are grateful to Heraldo Britski, Naercio Menezes, Geraldo Mendes dos Santos, Michel Jegu and Lucia Py-Daniel for help in the identification of specimens.

\section{Literature Cited}

Annibal, S. R. P. 1982. Avaliação bio-ecológica e Pesqueira das "Pescadas" (Plagioscion squamosissimus Heckel, 1840 e Plagioscion montei Soares, 1978) no "sistema Lago do Rei", Ilha do Careiro, AM. Unpublished Msc. Thesis, Instituto Nacional de Pesquisas da Amazônia, Fundação Universidade do Amazonas, Manaus. 162p.

Araujo Lima, C. A. R. M. 1994. Egg size and larval development in Central Amazonian fish. Journal of Fish Biology, 44: 371-389.

Araujo Lima, C. A. R. M., A. A. Agostinho \& N. N. Fabre. 1995. Trophic aspects of fish communities in Brazilian rivers and reservoirs. Pp. 105-136. In: J. G. Tundisi, C. E. M. Bicudo \& T. Matsamura Tundisi (Eds). Limnology in Brazil. São Paulo, Brazilian Academy of Sciences/Brazilian Limnological Society, 376p.

Brandorff, G. O. 1977. Untersuchungen zur PopulationsDynamik des Crustaceenplanktons im tropischen Lago Castanho, Amazonas, Brasilien. Unpublished Ph.D. Dissertation, Universität Kiel, Germany.

Burgess, W. E. 1989. An Atlas of Freshwater and Marine Catfishes. USA, t.f.h. publications, 784 p.

Carvalho, F. M. 1980. Alimentação do mapará (Hypophthalmus edentatus Spix, 1829) do lago do Castanho, Amazonas (Siluriformes, Hypophthalmidae). Acta Amazonica, 10: 545555. 
Carvalho, J. L. de 1978. Contribuição ao conhecimento da biologia do mapará, Hypophthalmus perporosus Cope 1878 (Pisces, Hypophthalmidae), no baixo e médio Tocantins. Boletim da Faculdade de Ciências Agrárias do Pará, 10: 37-57.

Carvalho, J. L., A. C. Coelho \& E. Toda. 1978. Hábito alimentar do Mapará, Hypophthalmus perporosus Cope 1878 (Pisces, Hypophthalmidae). Boletim da faculdade de Ciências Agrárias do Pará, 10:17-35.

Carvalho, M. L. \& M. Goulding. 1985. On the feeding ecology of the catfish Hypophthalmus fimbriatus in the blackwater Rio Negro of the Amazon basin. Revista Brasileira de Zoologia, 3: 33-41.

Cox-Fernandes, C. 1997. Lateral migration of fishes in Amazon floodplains. Ecology of Freshwater Fish, 6: 36-44

Cox-Fernandes, C. \& B. de Mérona. 1988. Lateral migration of fishes on a floodplain system in the Central Amazon (Careiro Island, Lake of Rei) AM-BR. Memoria Sociedad La Salle de Ciencias Naturales, 48: 409-432.

Ferreira, E. J. G. 1981. Alimentação dos adultos de doze espécies de Cichlideos (Perciformes, Cichlidae) do Rio Negro, Brasil. Unpublished Msc. Thesis, Instituto Nacional de Pesquisas da Amazônia, Fundação Universidade do Amazonas, Manaus. 252p.

Ferreira, E. J. G. 1984. A ictiofauna da represa hidrelétrica de Curuá-Una, Santarém, Pará. II - Alimentação e hábitos alimentares das principais espécies. Amazoniana, 9: 1-16.

Géry, J. 1977. Characoids of the World. USA, t.f.h. publications, $672 \mathrm{p}$.

Gottsberger, G. 1978. Seed dispersal by fish in the inundated region of Humaita, Amazonia. Biotropica, 10: 170-183.

Goulding, M. 1980. The fishes and the forest. Berkeley, University of California Press, 280 p.

Goulding, M., M. L. Carvalho \& E. G. Ferreira. 1988. Rio Negro. Rich life in poor water. The Hague, SPB Academic Publishing bv, $200 \mathrm{p}$.

Goulding, M. \& J. G. Ferreira. 1984. Shrimp-eating fishes and a case of prey-switching in Amazon Rivers. Revista Brasileira de Zoologia, 2: 85-97.

Hahn, N. S., A. A. Agostinho \& R. Goiten. 1997. Feeding ecology of Curvina Plagioscion squamosissimus (Heckel, 1840) (Osteichthyes, Perciformes) in the Itaipu Reservoir and Porto Rico Floodplain. Acta Limnologica Brasiliensia, 9: 11-12

Hahn, N.S., A. A. Agostinho, L. C. Gomes \& L. M. Bini. 1998. Estrutura trófica da ictiofauna do reservatório de Itaipu (Paraná-Brasil) nos primeiros anos de sua formação. Interciencia, 23(5): 299-305.

Honda, E. M. S. 1974. Contribuição ao conhecimento da biologia de peixes do Amazonas. II - Alimentação do tambaqui, Colossoma bidens (Spix). Acta Amazonica, 4: 47-53.

Horeau, V., P. Cerdan, \& S. Richard. 1996. Importance des apports exogènes dans le régime alimentaire de quelques poissons de "criques " du bassin versant du fleuve Sinnamary (Guyane française). Revue d'Ecologie (Terre et Vie), 51: 29-41.
Horn, H. S. 1966. Measurement of 'Overlap' in comparative ecological studies. American Naturalist, 100: 419-424

Hutchinson, G. E. 1957. Concluding remarks. Cold Spring Harbor Symposium. Quantitative Biology, 22: 415-427.

Junk, W. J., G. M. Soares \& F. M. Carvalho. 1983. Distribution of fish species in a lake of the Amazon river floodplain near Manaus (lago Camaleão) with special reference to extreme oxygen conditions. Amazoniana, 7: 397-431.

Kern, J. \& A. Darwich. 1997. Nitrogen turnover in the várzea. Pp. 118-135. In: W. J. Junk (Ed). The central Amazon floodplain. Ecology of a plusing system. Berlin, New York and London: Springer-Verlag, 525p.

Knöppel, H.-A. 1970. Food of central amazonian fishes. Contribution to the nutrient-ecology of Amazonian rainforest-streams. Amazoniana, 2: 257-352.

Knöppel, H.-A. 1972. Zur Nahrung tropischer Süßwasserfische aus Südamerika. Einige ausgewählte Arten der Anostomidae, Curimatidae, Hemiodidae und Characidae (Pisces, Characoidei). Amazoniana, 3: 231-246.

Kullander, S. O. 1994. Amazonische Cichliden -jenseits der Flußbiegung. DATZ Sonderh: 53-59

LeBail, P. -Y., P. Keith \& P. Planquette. 2000. Atlas des poissons d'eau douce de Guyane. Tome 2, fasc. II: Siluriformes. Patrimoines Naturels (M.N.H.N./CSP), 43(II): $307 p$.

Levins, R. 1968. Evolution in changing environments. Princeton, New Jersey: Princeton University Press, 130p.

Linton, L. R., R. W. Davies \& F. J. Wrona. 1981. Resource utilization indices: an assessment. Journal of Animal Ecology, 50: 283-292

Lowe-McConnell, R. H. 1964. The fishes of the Rupununi savanna district of British Guiana, South America. Part 1. Ecological groupings of fish species and effects of the seasonal cycle on the fish. Journal of the Linnean Society (Zoology), 45 (304): 103-144.

Lowe-McConnell, R. H. 1987. Ecological studies in tropical fish communities. Cambridge: Cambridge University Press, $382 \mathrm{p}$.

Marlier, G. 1968. Etudes sur les lacs de l'Amazonie centrale.II Le plancton. III- Les poissons du lac Redondo et leur régime alimentaire; les chaînes trophiques du lac $\mathrm{Re}$ dondo; les poissons du rio Preto da Eva. Caderno da Amazonia, 5: 6-57.

Mérona, B. de \& M. M. Bittencourt. 1993. Les peuplements de poissons du "Lago do Rei", un lac d'inondation d'Amazonie Centrale: description générale. Amazoniana, 12: 415-441.

Mérona, B. de, G. M. dos Santos \& R. G. de Almeida. 2001. Short term effects of Tucurui Dam (Amazonia, Brazil) on the trophic organization of fish communities. Environmental Biology of Fishes, 60: 375-392.

Mérona, B. de, R. Vigouroux \& V. Horeau. 2003. Changes in food resources and their utilization by fish assemblages in a large tropical reservoir in South America (Petit-Saut dam, French Guiana). Acta Oecologica, 24: 147-156. 
Morisita, M. 1959. Measuring interspecific association and similarity between communities. Memoria Faculty of Science Kyushu University Serie E (Biology), 3: 65-80.

Odinetz-Collart, O. 1991. Stratégie de reproduction de $M a$ crobrachium amazonicum en Amazonie centrale (Decapoda, Caridea, Palaemonidae). Crustaceana, 61: 253270.

Petry, P. 1989. Deriva de ictioplankton no Paraná do Rei, várzea do Careiro, Amazônia Central, Brasil. Unpublished Msc. Thesis, Instituto Nacional de Pesquisas da Amazônia, Fundação Universidade do Amazonas, Manaus. 68p.

Pianka, E. R. 1969. Sympatry of desert lizards (Ctenotus) in western Australia. Ecology, 50: 1012-1030.

Pianka, E. R. 1973. The structure of lizard communities. Annual Review of Ecology and Systematics, 4: 53-74

Planquette, P., P. Keith \& P. -Y. LeBail. 1996. Atlas des poissons d'eau douce de Guyane (tome 1). Collection du Patrimoine Naturel, vol. 22. IEGB - M.N.H.N., INRA, CSP, Min. Env., Paris, $429 \mathrm{p}$.

Pouilly, M., F. Lino, J. -G. Bretenoux \& C. Rosales. 2003. Dietary morphological relationships in a fish assemblage of the Bolivian Amazonian floodplain. Journal of Fish Biology, 62: $1137-1158$

Ross, S. T. 1986. Resource partitioning in fish assemblages: a review of field studies. Copeia, 2: 352-388.

Santos, G. M. dos. 1981. Estudos de alimentação e hábitos alimentares de Schizodon fasciatus Agassiz, 1829, Rhytiodus argenteofuscus Kner 1859, do lago do Janauacá - AM (Osteichthyes, Characoidei, Anostomidae). Acta Amazonica, 11:267-284.

Santos, G. M. dos. 1991. Pesca e ecologia dos peixes de Rondônia. Unpublished Ph. D. Dissertation, Instituto Nacional de Pesquisas da Amazonia, Fundação Universidade Federal do Amazonas, Manaus. 213p.

Santos, G. M. dos, M. Jegu \& B. de Mérona. 1984. Catálogo de peixes comerciais do baixo rio Tocantins. Brasília, Eletronorte, $83 \mathrm{p}$.

Saul, W. G. 1975. An ecological study of fishes at a site in upper Amazonian Ecuador. Proceedings of the Academy of Natural Sciences of Philadelphia, 127: 93-134.

Sazima, I. \& F. A. Machado. 1990. Underwater observations of piranhas in western Brazil. Environmental Biology of Fishes, 28: 17-31.
Schmidt, G. W. 1973. Primary production of phytoplankton in the three types of Amazonian waters. III. Primary production of phytoplankton in a tropical floodplain lake of Central Amazonia, Lago do Castanho, Amazon, Brazil. Amazoniana, 4: 379-404.

Schmidt, G. W. 1982. Primary production of phytoplankton in the three types of Amazonian waters. V. Some investigations on the phytoplankton and its primary productivity in the clear water of the lower rio Tapajos (Pará, Brazil). Amazoniana, 7: 335-348.

Schoener, T. W. 1985. Some comments on Connell's and my reviews of field experiments on interspecific competition. The American Naturalist, 125: 730-740.

Schwassmann, H. O. 1978. Times of annual spawning and reproductive strategies in Amazonian fishes. Pp. 187-200. In: J. E. Thorpe (Ed). Rhythmic activity of fishes. London, Academic Press.

Soares, M. G. M., R. G. Almeida \& W. J. Junk. 1986. The trophic status of the fish fauna in Lago Camaleão, a macrophyte dominated floodplain lake in the middle Amazon. Amazoniana, 9: 511-526

Weber, G. E. 1997. Modelling nutrient fluxes in floodplain lakes. Pp. 109-117. In: W. J. Junk (Ed). The central Amazon floodplain. Ecology of a pulsing system. Berlin, NewYork and London: Springer-Verlag, 525p.

Winemiller, K. O. 1989. Ontogenic diet shifts and resource partitioning among piscivorous fishes in the Venezuelan llanos. Environmental Biology of Fishes, 26: 177-199.

Wortmann, H. O. 1982. Aspekte der Biologie zweier Sciaenidenarten, der Pescadas Plagioscion squamosissimus (HECKEL) und Plagioscion montei (SOARES) in verschiedenen Gewässertypen Zentralamazoniens. Doktorgrade Dissertation, Institut für Meereskunde an der ChristianAlbrechts-Universität Kiel, Germany. 176p.

Zaret, T. M. \& A. S. Rand. 1971. Competition in tropical stream fishes: support for the competitive exclusion principle. Ecology, 52:336-342.
Received January 2004 Accepted May 2004 